\title{
К ИСТОРИИ ПЕРЕСЕЛЕНИЯ МОРДВЫ НА ТЕРРИТОРИЮ КРЫМСКОГО ПОЛУОСТРОВА: ПО РЕЗУЛЬТАТАМ ЭТНОГРАФИЧЕСКОЙ ЭКСПЕДИЦИИ*
}

\begin{abstract}
Целью исследования является изучение культуры и быта переселенцев из Мордовии, проживающих на территории Крымского полуострова. В статье на основе статистических данных, приведенных в переписях населения, проводимых на территории Российского государства в разные периоды его развития (1897, 1926, 1939, 1959, 1970, 1979, 1989, 2014), в Украине в период принадлежности изучаемого региона её юрисдикиии (2001), выявляются основные этапь заселения мордвы в Крым. Авторами дается характеристика факторов, влиявших на особенности переселения в конкретные исторические отрезки времени: сочиально-исторических, политических, экономических и т.д. В статье также приводятся сведения, полученные в ходе этнографической экспедиции в Крым, состоявшейся в 2018 г. под руководством д.и.н., профессора Л.И. Никоновой*. Полевой материал сопровождает описание преимущественно последних этапов заселения мордвы на территорию полуострова, дополняя информацию, полученную из официальных источников и научной литературы. Анализ динамики численности, статистических данных и полевого материала позволяет сделать вывод о частичной утрате традиционньх черт и культурных особенностей мордовским населением в связи с влиянием сочиильно-экономических реалий, унифицирующей среды полиэтничного региона, где за общую единицу общения выборается государственный язык, условия дисперсного расселения представителей этого народа по региону.
\end{abstract}

Ключевые слова: мордва, Мордовия, Крым, динамика численности, миграция, традиционная культура, полиэтническая среда

Ссылка при цитировании: Никонова Л.И., Трибушинина С.Д. К истории переселения мордвы на территорию Крымского полуострова: по результатам этнографической экспедиции // Вестник антропологии, 2022. № 1. С. 161-173.

Никонова Людмила Ивановна - д.и.н., профессор, ведущий научный сотрудник отдела региональных исследований и этнологии, НИИ гуманитарных наук при Правительстве Республики Мордовия (430005 Саранск, ул. Л. Толстого, д. 3). Эл. почта: congress7@list.ru. ORCID: htpps:// orcid.org/0000-0003-4327-9534

Трибушинина Светлана Дмитриевна - к. культурологии, старший научный сотрудник отдела региональных исследований и этнологии, НИИ гуманитарных наук при Правительстве Республики Мордовия (430005 Саранск, ул. Л. Толстого, д. 3). Эл. почта:tribushinina85@mail.ru ORCID: htpps://orcid.org/0000-0002-3472-3640

* 03.06-14.06.2018 по приглашению Севастопольского регионального отделения ООО «Ассамблея народов России» по проекту реализованного с использованием гранта Президента Российской Федерации на развитие гражданского общества, представленного Фондом президентских грантов (участники этноэкспедиции: Л.И. Никонова - руков., Т.Н. Охотина, С.Д. Трибушинина). 
DOI: $10.33876 / 2311-0546 / 2022-1 / 161-173$

(C) L.I. Nikonova, S.D. Tribushinina

\section{ON THE HISTORY OF THE MIGRATION OF MORDVINS TO THE CRIMEAN PENINSULA: THE RESULTS OF AN ETHNOGRAPHIC EXPEDITION}

The research aims to study the culture and daily life of the Mordvins living on the Crimean peninsula. The article reveals the main stages of the settlement of the Mordvins in Crimea, based on the population censuses conducted by the Russian state (in 1897, 1926, 1939, 1959, 1970, 1979, 1989, 2014) and by Ukraine when Crimea was subject to its jurisdiction (in 2001). The authors describe sociohistorical, political, economic, and other factors that influenced resettlement in specific historical periods. The article also provides data obtained during an ethnographic expedition to Crimea, held in 2018 under the leadership of Dr. of History Prof. L.I. Nikonova. The field material accompanies the description of the last stages of the Mordvins' settlement on the peninsula and supplements the information obtained from official sources and scientific literature. An analysis of the statistical data and field material allows us to conclude that the Mordovian ethnic group partially lost its traditional cultural identity due to the influence of socio-economic realities and the unifying environment of the multiethnic region. Mordvins are scattered widely across the region, and the state language has been chosen as the main unit of communication.

Keywords: Mordvins, Mordovia, Crimea, population dynamics, migration, traditional culture, multiethnic environment

For Citation: Nikonova, L.I., Tribushinina, S.D. 2022. On the History of the Migration of Mordvins to the Crimean Peninsula: the Results of an Ethnographic Expedition. Herald of Anthropology (Vestnik Antropologii) 1: 161-173.

Authors Info: Nikonova, Lyudmila I. - Dr., Prof., Leading Researcher, Institute for Humanities under the Government of the Republic of Mordovia (Saransk, Russian Federation). E-mail: congress7@list.ru. ORCID: htpps://orcid.org/00000003-4327-9534

Tribushinina, Svetlana D. - PhD in Culture Studies, Senior Researcher, Institute for Humanities under the Government of the Republic of Mordovia (Saransk, Russian Federation). E-mail: tribushinina85@mail.ru ORCID: htpps://orcid. org/0000-0002-3472-3640

Funding: The study was carried out with the financial support of The President's Grant Foundation

\section{Введение}

Крым является одним из миграционно-привлекательных регионов, представляющим особый интерес в геополитическом плане как территория с выходом в Черное 
море и как уникальный природно-климатический объект с обширными аграрными и рекреационными ресурсами. История Крымского полуострова чрезвычайно динамична: войны, революция, национальные движения, миграции и депортации с ними связанные не могли не сказаться на этническом составе полуострова. Не случайно Крым часто называют «своеобразным миграционным перекрестком» (см., например: Сидоренко 2012: 141). Во все времена он отличался полиэтническим характером, оказывавшим влияние на всех представителей проживающих здесь народов. В данной статье объектом изучения выступает история переселения в Крым представителей мордовского народа. Первая мордва поселилась в Крыму в XIX в. В попытке восстановления картины первых переселений на полуостров авторы обращаются к Памятным книгам Таврической и Тамбовской губерний, где отражены данные о мордве-переселенцах и мордве-отходниках, данным Первой всеобщей переписи населения Российской империи 1897 года. В дальнейшем этапы заселения выстраиваются на основе значимых в истории Крыма периодов, оказавших влияние на численный и этнический состав населения на протяжении XX в., как негативных (Первая мировая война, Революция, Гражданская и Великая Отечественная войны и др.), так и положительных (запуск Северо-Крымского канала, развитие промышленных предприятий и т.д.). В разные годы численность мордвы варьировалось в зависимости от исторических реалий конкретного периода, о чем свидетельствуют данные переписей населения 1926, 1939, 1959, 1970, 1979, 1989 (в составе СССР), 2001 (в составе Украины), 2014 (в составе РФ). К 2014 году на полуострове проживал 1601 представитель мордовского народа (Национальный состав 2018). Для подтверждения выкладок, сделанных на основе анализа статистических источников и научной литературы, авторы приводят данные, полученные в ходе этнографической экспедиции в Крым, состоявшейся в 2018 г. под руководством доктора исторических наук, профессора Л.И. Никоновой. Полевой материал сопровождает преимущественно последние этапы истории заселения мордвы ввиду возрастного состава респондентов, что делает анализ этих периодов более полным, а также позволяет проанализировать не только демографические особенности истории на каждом этапе, но и степень сохранности традиционной мордовской культуры и языковых данных в условиях проживания в полиэтническом регионе.

\section{Этапы переселения представителей мордвы в Крымский регион}

История заселения территории Крыма представителями мордвы началась в XIX в. Этапы формирования мордовского населения полуострова проходили в рамках периодов, характерных для представителей большинства народов материковой России, переселившихся на полуостров, и соответствовали миграционной и экономической политике Российской империи и Советского Союза. Заселение полуострова представителями народов, проживавших на материковой части Российского государства, началось после присоединения Крыма 21 апреля (8 апреля по старому стилю) 1783 г. в соответствии с Манифестом Екатерины II «О принятии Крымскаго полуострова, острова Тамана и всея Кубанской стороны под державу Российскую» (ПСЗ РИ 1830). Первым русским населенным пунктом в Крыму считается село Санкт-Петербургские Мазанки (ныне с. Мазанка Симферопольского района РК), основанное в 1784 г. 69 демобилизованными из армии солдатами 2-го и 3-го Гренадерских полков 
(Мазанка 2017). Точных сведений о переселении непосредственно мордвы на территорию полуострова в официальной литературе в это время не зафиксировано.

Первый этап заселения мордвы включает период до 1897 г., когда в результате Первой всеобщей переписи населения Российской Империи было установлено, что на территории полуострова проживает 123 представителя мордовского населения (Первая всеобщая перепись 1904: 143). Наиболее вероятно, что переселение первых представителей связано с аграрным развитием региона. Освободившиеся в результате оттока крымско-татарского, турецкого и ногайского населения на территорию Османской Империи после присоединения полуострова в к. XVIII в. и после Крымской войны с Турцией (1853-1856) территории требовали привлечения большого количества земледельцев, способных развивать сельское хозяйство в разных сферах. Существенную роль здесь также сыграло расширение земель, пригодных для сельскохозяйственной деятельности, после проведения в 1860-1862 гг. мелиорационных работ в районах, ранее характеризовавшихся как крайне засушливые, например, Евпаторийском, Перекопском, Симферопольском и др., где были вырыты колодцы, прорыты водные каналы и созданы другие искусственные водоемы (Памятная книга Таврической губернии 1867: 175). Активное развитие сельского хозяйства привлекало представителей разных народов России и Европы. Мордва как народ земледельческий также приезжала в Крым на заработки. Таврическую губернию, в состав которой входил Крым, В. И. Чаславский отмечал среди наиболее благоприятных для сельскохозяйственного отходничества. Он писал, что из Тамбовской, Пензенской и Симбирской губерний, где мордва была вторым по численности населения народом (Тамбовская - 89704 чел. (3,34\%), Пензенская - 187862 (12,78\%), Симбирская - $188980(12.37 \%)^{1}$ жители выезжали на заработки по причине малоземелья либо полного безземелья и, в некоторых местах, неплодородности выделенных в надел земельных участков (Чаславский 1875: 3). В «Сборнике статистических статей по Тамбовской губернии» приводятся данные о представителях мордовского народа, годами проживавших на территории полуострова: 130 человек из сел Широмасово и Шокши Широмасовской волости Тамбовской губернии, из Теньгушеской волости в отхожих промыслах числилось 180 чел., «главная часть ихъ въ Крыму (...) Проживающих въ Крыму оказалось большая часть изъ с. Нороватова (прим. автора: ныне с. Нароватово Теньгушевского р-на Республики Мордовия, основное население: мордва-эрзя)» (Сборник 1883: 200). Косвенным подтверждением как основной причины переезда наличие земледельческого заработка может служить также превалирование среди представителей мордвы в XIX в. сельского населения над городским ( $72 \%$ сельское) и мужского пола над женским $(66,8 \%$ мужчин), о чем свидетельствуют данные Первой всеобщей переписи населения Российской Империи (Первая всеобщая перепись 1905: Табл. ХІІІ).

Второй период характеризуется снижением численности мордовского народа в 1920-е гг. из-за происходивших в начале XX века негативных событий в истории Крыма и России в целом. Во время Первой мировой войны береговая линия Крыма длительный период подвергалась бомбардировкам со стороны моря. Часть мужского населения была мобилизована. Численность населения снизилась в 1917 году в период Октябрьской революции и Гражданской войны. В конце весны 1918 г. после падения монархического строя в Российской Империи полуостров был оккупирован немецкими войсками под командованием генерала Коша (три пехотные дивизии и

${ }^{1}$ Прим. автора: численность и процент мордовского населения от общего населения в губерниях. 
конная бригада) (Пученков 2015), в горном Крыму и на побережье в это время вспыхнуло восстание крымских татар, названное ими «народной войной», в ходе которого была развернута борьба с христианским населением полуострова (Киселева 2015: 38 ), что тоже приводило к изменению численности населения не в лучшую сторону. Активные политические события в период революции и Гражданской войны привели к сокращению городского населения (Зарубин 2013). Н. В. Киселёва отмечает, что сельское население Крыма до начала 1920-гг. практически не пострадало. Однако, в 1920 г. и 1921 г. люди столкнулись с сильной засухой, вызвавшей голод на селе (Kuселева 2015: 40). Усугубляло его и расположение частей Красной армии, стянутых из разных регионов России, которые снабжались за счет местного населения, в том числе промышляли грабежами (Соколов 2012). Это стало причиной переселения части местного населения из сельской местности в города. Такая картина характерна и для мордовского населения. Согласно Переписи 1926 г. в Крыму проживало 53 представителя мордвы, 37 из которых в городах (Всесоюзная перепись 1926).

С конца 1920-х гг. - нач. 1930-х гг. общая численность населения постепенно начинает увеличиваться. В литературе, освещающей историю заселения Крыма, отмечается что часть мордвы из различных областей РСФСР переселяется в ряд крымских сел в 1920-е - 1930-е гг. (Обличчя 2012: 359). Один из представителей мордовского народа, опрошенный в ходе экспедиции, В.Н. Болотников вспомнил, что родственники его матери приехали в Крым работать еще до начала Великой Отечественной войны (ПМА 1). Всесоюзной переписью 1939 г. зафиксировано 810 чел. мордвы. Современная наука с осторожностью принимает результаты указанной переписи, однако, на ее основании можно сделать вывод об увеличении численности мордвы на территории полуострова (Волков 1990).

Третий этап переселения мордвы в Крым начался после Великой Отечественной войны и связан с её последствиями. Местное население полуострова сократилось почти вдвое в результате активных боевых действий, немецкой оккупации, характеризовавшейся уничтожением значительной части местного населения, в т.ч. геноцида еврейского народа, и массовой депортации представителей ряда народов: немцев (1941), крымских татар, греков, болгар и др. (1944). После освобождения Крыма в 1944 году были приняты меры по восстановлению сельского хозяйства и городов. Согласно постановлению Госкомитета обороны № ГОКО-6372 от 12 августа 1944 г. «О переселении колхозников в районы Крыма» сюда переселяли крестьян из областей Украинской ССР, Краснодарской, Курской, Ростовской, Тамбовской и др. областей для восстановления сельского хозяйства (Конониренко 2017: 99). В перечень требовавшихся в селах специалистов входили не только колхозники, но и председатели колхозов и совхозов, учителя, врачи, механики, агрономы, зоотехники и т. д. Колхозники и специалисты из Тамбовской области, в которой по переписи 1939 г. мордвы проживало 1010 чел., были направлены в Карасубазарский район (ныне Белогорский) Республики Крым (численность мордвы на 2014 год - 37 чел.), из Ростовской, в которой числилось 1724 чел., в Ялтинский район (численность мордвы на 2014 год - 97 чел.) и т. д. (Там же). Приезжавшим в Крым по переселенческой программе предоставлялся ряд налоговых льгот, единовременное денежное пособие в размере 2500 руб. на семью, обеспечение продуктами сельского хозяйства, жильем, оставшимся от депортированных народов, их хозяйствами, урожаем и др. (Вербицкая 1986: 18).Э.И. Сеитова отмечает, что в этот период работники в колхозы и совхозы 
приезжали не только по программе переселения, но и в частном порядке. Сложно сказать были ли среди приехавших представители мордовской национальности, однако, ввиду увеличения численности мордвы к переписи 1959 года, можно предположить, что такие случаи имели место. Максименко М. М. пишет, что согласно данным Государственного Киевского архива на территорию Крыма с весны 1944 по 1947 гг. переселилось 2377 семей из 27 регионов СССР (Максименко 1990: 53). Необходимо отметить, что в послевоенный период в восстановлении нуждались и города Крыма (Евпатория, Керчь, Севастополь, Симферополь и др.), которые сильно пострадали в период боев и немецкой оккупации. Представители мордвы приняли участие в этом процессе. Например, согласно архивным данным, в 1948 г. на восстановление г. Севастополь было направлено 250 чел. из Мордовской АССР (ЦГА РМ 1948: 1156-1157).

Переселенческие программы продолжали действовать и после изменения административного статуса Крымской области в связи с выходом Указа Президиума Верховного Совета СССР«О передаче Крымской области из состава РСФСР в состав Украинской ССР» от 19 февраля 1954 года. Как отмечает Э. Сеитова, сельскому хозяйству по-прежнему требовались квалифицированные трудоспособные работники (Сеитова 2010: 319). Так, по программе переселения в Крым приехала семья И.П. Сараева в составе 5 чел., И. и Е. Поздняковы и др. (ПМА 1). По словам В.А. Конониренко, в 1950-х гг. приезжало также большое количество самовольных переселенцев, например, за 1950-й г. в Крым приехало 513 семей из Пензенской области (Конониренко 2017: 119). Часть переселенцев из Мордовии приезжала в города, например, Ф. И. и А. И. Родионовы, затем их внучка Н.В. Сетяева (ПМА 1), В.Д. и Е.Д. Романовы, Е. Барабаш и др. (ПМА 2). В результате осуществления переселенческих государственных программ и самовольных переездов численность мордвы на территории Крыма увеличилась и по данным Всесоюзной переписи 1959 г. составила уже 1858 чел. (790 м., 1068 ж.) (ВПН 1959).

Четвертый этап миграции мордвы в Крым включает 1960-80-е гг. Численность мордовского населения значительно выросла: в 1970-м г. она составила 3179 чел., в 1972 - 3970 чел., в 1989 - 4582 чел. Значительному миграционному притоку способствовало активное развитие экономики Крыма в этот период. Сельскохозяйственный сектор получил новый виток развития со строительством Северо-Крымского канала, позволившим увеличить площадь колхозов, привлекающих для работы новых переселенцев. К 1970-му году в Крыму насчитывалось 119 колхозов площадью 470 тыс. г (История сел 1974: 63). Среди опрошенных в ходе экспедиции были представители мордовской национальности, приехавшие работать в крупные сельхозпредприятия Красногвардейского (совхозы «Дружбы народов», «Восход», колхозы «Маленький», «Россия» и др.), Сакского (совхозы «Береговой», «Крымский», «Озерный», «Россия» и др.), Симферопольского (совхоз «Пригородный», «Советская Родина» и др.), Советского и др. районов с развитым агропромышленным комплексом. Представители местного мордовского сообщества рассказали, что 3-5 представителей мордовской национальности проживали почти в каждом крымском селе (ПМА 2). В 1976 г. программы переселения в сельские районы были закрыты после решения властей о демографическом насыщении Крыма (Гусаков 2019: 75). Однако, это не уменьшило приток мордовского населения, но сместило вектор миграции с сельской местности в сторону городов. Согласно Статистическому бюллетеню «Итоги Всесоюзной переписи населения 1989 года по городам 
и районам Автономной республики Крым», изданной в Симферополе в 1991 году, в Крыму в этот период проживало 4 тыс. чел., из которых в городах и поселках городского типа проживало 1457 чел., а в сельской местности - 2543 чел. (Финогеев, Шостка, Старчков 2009: 28). При общем увеличении численности мордвы к 1989 году за счёт мордвы г. Севастополь, где на то время проживало более 500 представителей этого народа, численность городской мордвы начинает превалировать над сельской. Увеличению численность городского населения послужил и тот факт, что часть мордовского населения, изначально приехавшая в сельскую местность, в этот период переехала в города, например, в г. Севастополь переехали Л.В. Ильченко (Бойко), Н.Н. и А.И. Балашовы, В.А. Романов с семьей и др. (ПМА 2), в г. Симферополь переселились В.М. Старчков, В.И. Болотников и т.д. (ПМА 1). Увеличилось количество миграций непосредственно в города. Напр., в 1970-1980-х гг. в Крым приехали работать Т.И. Мялькин, Б.А. Суркова, Н.А. Федосеева, Н.Н. Жданкина, В.С., А.С. и В.А. Четыркины, М.В. Грибанова (Видяева) и др. (г. Севастополь), в г. Саки приехал В.П. Наумкин, переселившийся затем в г. Гурзуф и др. (ПМА 1, 2).

В дальнейшем ситуация с постепенным ростом динамики численности мордовского населения кардинально изменилась. После распада СССР Крым остался в составе новообразованного государства Украина как Крымская Автономная Советская Социалистическая Республика согласно закону УССР от 12 февраля 1991 года. В 1992 году автономия была переименована в Республику Крым (Закон 1992: 194), а в 1994 году - в Автономную Республику Крым. После принятия Конституции Украины в 1996 г. из состава Автономной Республики Крым был исключен город Севастополь, который согласно ст. 133 указанного документа приобрёл специальный статус административной единицы первого уровня наравне со столицей Украины г. Киевом (Конституція України 1996). В этот период общая численность населения полуострова значительно снизилась в связи с ухудшением социально-экономической жизни, так, например, в г. Севастополь сократилось число промышленных предприятий с 75 до 51, что послужило росту безработицы и привело к снижению естественного прироста населения и миграциям (Севастополь 2008: 31). Также вынужденной миграции славянского населения совместно с которым из Крыма уезжала и часть представителей мордвы способствовал рост межэтнической напряжённости в связи с репатриацией крымско-татарского населения (Гусаков 2019: 75). По Всеукраинской переписи населения 2001 г. в Автономной Республике Крым проживало 2208 чел. мордвы, имеющей украинское гражданство и 39 чел. граждан других государств и лиц, не имеющих гражданства (Распределение граждан 2004).

В результате Референдума о статусе Крыма Республика Крым и город федерального значения Севастополь вошли в состав Российской Федерации на основании Федерального закона от 21 марта 2014 г. N 36-Ф3 «О ратификации Договора между Российской Федерацией и Республикой Крым о принятии в Российскую Федерацию Республики Крым и образовании в составе Российской Федерации новых субъектов» (Федеральный закон 2014). В этом же году была проведена перепись населения, установившая, что в Крымском Федеральном округе проживает 1601 представитель мордовского народа: 1338 чел. проживают в Республике Крым, в г. Севастополь - 267 чел.

Присоединение Крыма к России условно можно считать началом новой волны переселений, т.к. по данным Крымстата население полуострова в настоящее время постепенно увеличивается за счет приезжающих с материковой части России (Итоги 
2015; Демографическая ситуация 2018). Так, по данным Мордовиястат, в 2017 г. в Крым выехало из Мордовии 22 чел. (Миграция 2018: 12-13).

\section{Современная система материальной и духовной культуры мордвы Крымского полуострова в условиях поликультурного региона}

Сложившаяся в Крыму в процессе миграций уникальная полиэтническая среда, социально-экономическая ситуация в современном обществе и этническая дисперсность мордовских переселенцев оказывают значительное влияние на уровень этнической самоидентификации, в т.ч. языковых характеристик, степень сохранности традиционной материальной и духовной культуры мордвы. Процесс снижения численности мордовского населения на территории Крымского полуострова связан не только с естественной убылью населения и миграционными реалиями начала XXI в., но процессом ассимиляции. Об уровне ассимиляции народа в первую очередь свидетельствует степень сохранности языковых навыков среди его представителей, т.к. они утрачиваются первыми при общении в иной языковой среде. В первом же поколении переселенцев количество мордовскоговорящих представителей уменьшается. Ещё в «Памятной книге Таврической губернии за 1867 г.» о мордве, проживающей в русско-украинской среде с 1833 г. было написано: «В образе жизни, одежде, нравах и обычаях между ними и живущими в том же селении русскими, государственными крестьянами, почти не заметно никакого различия. Говорят они по-русски очень редко, между своими, по-мордовски» (цит. по: Памятная книга 1867: 205). По переписи 2014 года подавляющее большинство мордвы полуострова знают и считают родным языком русский, в то время как мордовским владеют 397 представителей из 1601. Также в Крымском Федеральном округе были также зафиксированы 1 человек, указавший в качестве родного мокша-мордовский язык, и 5 - эрзя-мордовский (Таблицы 2014).

Активизации процесса ассимиляции способствовало большое количество межнациональных браков. Согласно переписи 2014 г. в Крымском Федеральном округе было зафиксировано большое количество межнациональных браков - с русскими, украинцами, крымскими татарами и др. Они составляли более 30\% (Таблицы 2014). В ходе экспедиции межнациональные браки были зафиксированы и среди представителей мордовского народа. Например, А.С. Лебин женат на крымской татарке, В. Старчков и В.А. Романов - на украинках и т.д. (ПМА 1, 2).

В разной степени мордва сохранила ряд традиционных элементов этнокультуры. Преимущественно это касается приготовления традиционной пищи, как наиболее сохранной части материальной культуры народа. В целом рацион мордовского населения полуострова значительно расширяется по причине изменения социально-экономических условий проживания (увеличение доли покупных продуктов питания и др.), что характерно для всех регионов страны, смена диапазона пищевых привычек за счет продуктов, характерных для конкретных природно-климатических условий (увеличение в рационе овощей, фруктов, морской рыбы и т.д.), приготовление блюд из национальной кухни соседних народов (украинские борщ, зразы, налистники, крымско-татарские манты и чебуреки и т.д.). Свои национальные блюда постепенно переходят в разряд праздничных блюд, приготовление которых приурочено к календарным, церковным или семейным праздникам. Повсеместно в Крыму мордва готовит салмат или салму (галушки с мясом и тушеной капустой или яичницей), шенявкст (капуста 
тушеная с мясом), цүюморот, тёмара, сёмара (отваренная в тесте хамса), лям (суп с картофелем, мясом, луком и морковью), мордовские пшенные блины пача, naчат и т.д. Традиционные рецепты зачастую видоизменяются в силу отсутствия ряда продуктов, характерных для исконных мест проживания мордвы, напр., ржаная и пшенная мука в блинах заменяется пшеничной или крахмалом (ПМА 1, 2).

Изменения свадебных, похоронно-поминальных и др. обрядов связаны скорее с общими трансформациями, произошедшими в этой части традиционной культуры в советский период, нежели с переездом на новое место жительства. Большая часть опрошенных в ходе экспедиции переехала в Крым в 1960-70-е гг., когда и на исконной территории проживания мордвы в Мордовской АССР, Пензенской, Нижегородской, Ульяновской и др. областях происходил процесс унификации обрядов в соответствии с советскими социально-экономическими и политическими установками, выработки новой обрядовости, лишь частично сохранившей элементы традиционных верований и обрядов. Напр., в процессе осуществления свадебного обряда для предохранения молодых от негативного воздействия до настоящего времени вкалывают булавки либо иголки в подол одежды, пекут традиционные свадебные пироги и т.д.

Родинные обряды практически не сохранились в связи с развитием медицины, в результате которой роды проходят в медицинских учреждениях, однако, частично сохранился обряд занесения новорожденного в дом: в красном углу на стол кладется специально испеченный хлеб с воткнутой в центре церковной свечой, перед ним молятся о здоровье новоиспеченного члена семьи (ПМА 2). В отправлении похоронных обрядов сегодня большую роль играют православные традиции и современные похоронные тенденции (обращение в ритуальные службы и др.), но в то же время среди мордвы сохраняются его традиционные элементы. Напр., крымская мордва отмечает, что они стараются хоронить родных рядом с родственниками, как это принято на малой родине (ПМА 1, Н.Н. Сараев, В.М. Старчков и др.). В целом традиционная культура мордовского народа, проживающего в Крыму, постепенно видоизменяется, сохраняя при этом лишь ряд традиционных элементов.

\section{Заключение}

Таким образом, в результате анализа статистических и архивных данных, полевых материалов авторов в истории заселения мордовского народа на территорию Крымского полуострова можно выделить четыре основных этапа: до начала XX века, в 1920 - 30-е гг., 1940 - 50-е гг. и 1960 - 80-е гг. В настоящее время в связи с политическими изменениями последнего десятилетия можно сделать вывод о начале пятого этапа переселения. Изменения численности мордвы в Крыму непосредственно связаны с негативными и положительными моментами в истории изучаемого региона и соответствуют этапам заселения сюда русского и украинского населения. Основной приток мордовского населения пришелся на 1960 - 80-е гг. Сложившаяся в процессе миграций уникальная полиэтническая среда оказывает значительное влияние на традиционную материальную и духовную культуру жителей, переселивших на полуостров в разное время. Культура мордовских переселенцев впитала в себя традиционные элементы различных народов, проживающих на полуострове. Высока доля воздействия различных факторов, имеющих унифицирующий характер, таких как русская культура, религиозные основы православия, реалии рыночной экономики. 


\section{Источники и материалы}

ПМА 2018 № 1 - ПМА 2018, № 1. Республика Крым (Болотников В. Н., 1964 г. р., г. р., г. Симферополь; Сетяева Н. В., 1936 г. р., г. Симферополь, Власова (Зотова) 3. М., 1951 г. р., Власов И. Д., 1939 г. р., с. Белоглинка Симферопольского р-на; Киреев Ю. А., 1948 г. р., г. Симферополь; Лебин Виталий Сергеевич, 1976 г. р., г. Евпатория, Сараев Н. И., 1940 г. p., с. Кремнёвка Красногвардейского район; Старчков Владимир Михайлович, 1960 г. р., г. Симферополь).

ПМА 2018, № 2 - ПМА 2018, № 2. Город федерального значения Севастополь (Грибанова (Видяева) М. В., 1955 г. р., Жданкина Наталья Николаевна, 1962 г. р., Романов Виктор Андреевич, 1949 г. р., Суркова (Давыдкина) Татьяна Ивановна, 1964 г.р., Ильченко Л. В., 1950 г. р., Балашов Николай Николаевич, 1952 г. р., Сиркина Галина Алексеевна, 1947 г. р., Мялькин Борис Алексеевич, 1959 г. р.).

ЦГА - Центральный государственный архив Республики Мордовия. Р-228. Оп. 3. Д. 188. Постановления, решения суженных заседаний, районных исполнительных комитетов. Сводки о выполнении плана по валовой продукции государственной и кооперативной промышленности. Справки о выполнении государственного плана хлебопоставок, о состоянии животноводства и о ходе весеннего сева, о естественном движении населения. 1948. 1235 л.

ВПН 1926 - Всесоюзная перепись населения 1926 года. Национальный состав населения по регионам РСФСР // Демоскоп Weekly. Институт демографии НИУ ВШЭ имени А. Г. Вишневского. http://www.demoscope.ru/weekly/ssp/rus_nac_26.php?reg=788.

ВПН 1959 - Всесоюзная перепись населения 1959 года. Городское и сельское население областей республик СССР (кроме РСФСР) по полу и национальности // Демоскоп Weekly. Институт демографии НИУ ВШЭ имени А. Г. Вишневского. http://www.demoscope.ru/ weekly/ssp/resp_nac_59.php?reg=9.

ВПН 1970 - Всесоюзная перепись населения 1970 года. Городское и сельское население областей республик СССР (кроме РСФСР) по полу и национальности // Демоскоп Weekly. Институт демографии НИУ ВШЭ имени А. Г. Вишневского. http://www.demoscope.ru/ weekly/ssp/rus_nac_70_ra.php.

ВПН 1979 - Всесоюзная перепись населения 1979 года. Городское и сельское население областей республик СССР (кроме РСФСР) по полу и национальности // Демоскоп Weekly. Институт демографии НИУ ВШЭ имени А. Г. Вишневского. http://www.demoscope.ru/ weekly/ssp/rus_nac_79_ra.php.

ВПН 1989 - Всесоюзная перепись населения 1989 года. Городское и сельское население областей республик СССР (кроме РСФСР) по полу и национальности // Демоскоп Weekly. Институт демографии НИУ ВШЭ имени А. Г. Вишневского. http://www.demoscope.ru/ weekly/ssp/rus_nac_89_ra.php.

Демографическая ситуация 2018 - Демографическая ситуация в Республике Крым: аналитический доклад // Управление Федеральной службы государственной статистики по Республике Крым и г. Севастополю (Крымстат). Симферополь, 2018. 18 с.

Закон 1992 - Закон Крымской АССР от 26 февраля 1992 года № 19-1 «О Республике Крым как официальном названии демократического государства Крым» // Ведомости Верховного Совета Крыма. 1992. № 5. С. 194.

История 1974 - История городов и сел УССР в 26-ти т. Т. 26: Крымская область. Киев: Институт истории АН УССР, Украинская советская энциклопедия АН УССР, 1974. 623 с.

ИПН 2015 - Итоги переписи населения в Крымском федеральном округе /Федеральная служба государственной статистики. М.: ИИЦ «Статистика России», 2015. 279 с.

Конституція України 1996 - Конституція України 1996 // Законодавство України. Дата размещения: 01.01.2020. https://zakon.rada.gov.ua/laws/show/254к/96-вр.

Мазанка - Мазанка // Крымология 2.0. Дата публикации: 10.02.2017. http://krymology.ru/publ/ 
settlement/mazanka/9-1-0-349.

Миграция 2018 - Миграция населения Республики Мордовия за 2017 год. Статистический сборник № 903. Саранск, 2018. 52 с.

Национальный состав 2014 - Национальный состав и владение языками, гражданство: Итоги Переписи населения в Крымском федеральном округе 2014 года // Управление Федеральной службы государственной статистики по Республике Крым и г. Севастополю (Крымстат): официальный портал. Дата размещения: 2017. http://crimea.old.gks.ru/wps/wcm/connect/ rosstat_ts/crimea/ru/statistics/stat_Crimea/population/ (дата обращения: 21.09.2018 г.)

Обличчя Тавриди 2012 - Обличчя Тавриди. Народи: Альбом [Автор проекта Прокопенков В. М.] Симферополь, 2012. $400 \mathrm{c.}$

Памятная книга 1867 - Памятная книга Таврической губернии, изданная Таврическим губернским статистич. комитетом / Сост. под ред. К.В. Ханацкого. Вып. 1 Вып. 1. Симферополь: Типография губернского правления, 1867. 657 с.

Первая Всеобщая 1904 - Первая всеобщая перепись населения Российской империи, 1897 г. Т. 41: Таврическая губерния/ Под ред. Н.А. Тройницкого. СПб.: Издание Центрального статистического комитета Министерства внутренних дел, 1904. 310 с.

Первая Всеобщая 1905 - Первая Всеобщая перепись населения Российской Империи 1897 г. Под ред. Н.А. Тройницкого. Т. ІІ: Общий свод по Империи результатов разработки данных Первой Всеобщей переписи населения, произведенной 28 января 1897 года. СПб., 1905. Таблица ХІІІ. Распределение населения по родному языку.

ПСЗ РИ. Т. ХХІ. № 15708 - Полное собрание законов Российской империи с 1649 года: [Собрание 1-е: по 12 декабря 1825 г.]. - Санкт-Петербург: В типографии Второго отделения Собственной Его Императорского Величества канцелярии. 1830.

Распределение 2004 - Распределение граждан других государств и лиц без гражданства по национальности и полу // Государственный комитет статистики Украины. Дата размещения: 2004. http://2001.ukrcensus.gov.ua/rus/results/nationality_population/nationality_popul4/.

Сборник 1883 - Сборник статистических статей по Тамбовской губернии. Т.4: Темниковский уезд. Тамбов: Губернская земская типография, 1883. 240 с.

Перепись КФО - Таблицы с итогами Федерального статистического наблюдения «Перепись населения в Крымском федеральном округе» // Федеральная служба государственной статистики. https://www.gks.ru/free_doc/new_site/population/demo/perepis_krim/tab-krim.htm.

Ф3 2014 - Федеральный закон от 21 марта 2014 г. N 36-Ф3 «О ратификации Договора между Российской Федерацией и Республикой Крым о принятии в Российскую Федерацию Республики Крым и образовании в составе Российской Федерации новых субъектов» // Российская газета. URL: https://rg.ru/2014/03/22/krim-site-dok.html.

\section{Научная литература}

Вербицкая О.М. Плановое сельскохозяйственное переселение в РСФСР в 1946-1958 годах // Вопросы истории. № 12. Декабрь 1986. С. 13-26.

Волков А.Г. Перепись населения СССР 1937 года. История и материалы /Экспресс-информация. Серия «История статистики». Вып. 3-5 (часть II). М., 1990. С. 6-63.

Волобуев О.В. Сельское хозяйство Крыма в послевоенные (1944-1953) годы: динамика и тенденции развития // Вестник Московского государственного областного университета. Серия: История и политические науки. 2016. № 4. С. 92-100. С. 96.

Гусаков Т.Ю. Этнические миграции на Крымском полуострове (1783-2014 гг.) // Географический вестник = Geographical bulletin, 2019. № 4 (51). С. 69-81.

Зарубин В. Г. Проект «Украина». Крым в годы смуты 1917-1921 гг. Харьков: Изд-во Фолио, 2013. $384 \mathrm{c}$.

Киселёва Н.В. Этнополитические процессы в Крыму: исторический опыт, современные проблемы и перспективы их решения / Киселёва Н.В., Мальгин А.В., Петров В.П., Форман- 
чук А.А. Симферополь : Салта, 2015. 352 с.

Конониренко B.A. Демографическое и хозяйственное освоение территорий депортации Поволжья, Северного Кавказа и Крыма в 1941-1953 гг. Диссертация на соиск. науч. ст. канд. ист. наук. Саратов, 2017. 230 с.

Науменко Л., Аранджиони М. (сост.) КРУ Этнографический музей: путеводитель. Симферополь, 2012. $44 \mathrm{c.}$

Максименко М.М. Переселення в Крим сільського населення з інших районів СРСР (19441966) // Український історичний журнал, 1990. № 11. С. 52-58.

Пученков А.С. Крым в огне Гражданской войны: 1917-1920 гг. (Доклад на заседании Научного совета Российского военно-исторического общества) // История РФ: федеральный портал. Дата размещения: 13.07.2015. https://histrf.ru/read/articles/krym-v-oghnie-grazhdanskoivoiny-1917-1920-ghgh.

Севастополь: Энциклопедический справочник / Национальный музей героической обороны и освобождения Севастополя; Ред.-сост. М. П. Апошанская. 2-е изд., доп. и испр. Севастополь: Национальный музей героической обороны и освобождения Севастополя; Симферополь: Изд-во ООО «Фирма «Салта» ЛТД», 2008. 1120 с.

Сеитова Э.И. Система льгот для переселенцев в Крым в 1944-1964 годах // Ученые записки Таврического национального университета им. В. И. Вернадского. Серия «Исторические науки». Том 23 (62), № 1 : спецвыпуск «История Украины». 2010 г. С. 180-186.

Сеiтова E.I. Процес сільськогосподарської міграції до Криму протягом 1944-1953 років // «Сіверщина в історії України»: збірник наукових праць. 2010. Вип. 3. С. 317-320.

Сидоренко Н.А. Миграция и этнические процессы в Крыму в 40-70-е годы ХХ века // Вопросы духовной культуры - ИСТОРИЧЕСКИЕ НАУКИ, 2012. № 238. С. 141.

Соколов Д. Черное время Тавриды:Крымская деревня и голод 1921-1923 гг. // Православный информационный портал «Русская линия». Дата размещения: 23.07.2012. https://rusk.ru/ st.php?idar $=55994$.

Финогеев Б. Л., Шостка В. И., Старчков В.М. Мордовский этнос в полиэтничном населении Крыма: численность, расселение, трудовой менталитет, самобытность, ремесла. Симферополь: «Петит», 2009. 40 с.

Чаславский В.И. Земледельческие отхожие промыслы. СПб.: тип. В. Безобразова и К 1875. $31 \mathrm{c}$.

\section{References}

Aposhanskaya, M. P. 2008 Sevastopol': Enciklopedicheskij spravochnik [Sevastopol: Encyclopedic reference book] Sevastopol: National Museum of Heroic Defense and Liberation of Sevastopol. Simferopol: Publishing House LLC "Firm" Salta "LTD".

Chaslavskij, V.I. 1875 Zemledel'cheskie othozhie promysly [Agricultural latrine trades] Saint Petersburg: printing house V. Bezobrazov and $\mathrm{K}^{\circ}$.

Finogeev, B.L., V.I. Shostka, and V.M. Starchkov. 2009 Mordovskij etnos v polietnichnom naselenii Kryma: chislennost', rasselenie, trudovoj mentalitet, samobytnost', remesla. [Mordovian ethnos in the multiethnic population of Crimea: number, settlement, labor mentality, originality, crafts.] Simferopol: "Petit".

Gusakov, T.YU. 2019 Etnicheskie migracii na Krymskom poluostrove (1783-2014 gg.) [Ethnic migrations on the Crimean peninsula (1783-2014)]. Geographical bulletin 4 (51): 69-81.

Kiselyova, N.V. 2015 Etnopoliticheskie processy v Krymu: istoricheskij opyt, sovremennye problemy i perspektivy ih resheniya [Ethnopolitical Processes in Crimea: Historical Experience, Contemporary Problems and Prospects for Their Solution], edited by Kiselyova N.V., Malugin A.V., Petrov V.P., Formanchuk A.A. Simferopol: Salta.

Kononirenko, V.A. 2017 Demograficheskoe $i$ hozyajstvennoe osvoenie territorij deportacii Povolzh'ya, Severnogo Kavkaza i Kryma v 1941-1953 gg. [Demographic and economic 
development of the territories of deportation of the Volga region, the North Caucasus and the Crimea in 1941-1953]. Saratov.

Naumenko, L., and M. Arandzhioni. 2012 KRU Etnograficheskij muzej: putevoditel' [KRU Ethnographic Museum: Guide]. Simferopol.

Maksimenko, M.M. 1990 Pereselennya v Krim sil's'kogo naselennya z inshih rajoniv SRSR (1944-1966) [Resettlement of the rural population from other parts of the USSR to the Crimea (1944-1966)] Ukrainian Historical Journal 11: 52-58.

Puchenkov, A.S. 2015 Krym v ogne Grazhdanskoj vojny: 1917-1920 gg. (Doklad na zasedanii Nauchnogo soveta Rossijskogo voenno-istoricheskogo obshchestva) [Crimea in the fire of the Civil War: 1917-1920 (Report at the meeting of the Scientific Council of the Russian Military Historical Society)] History of the Russian Federation: federal portal. https://histrf.ru/read/ articles/krym-v-oghnie-grazhdanskoi-voiny-1917-1920-ghgh.

Seitova E. I. 2010 Sistema l'got dlya pereselencev v Krym v 1944-1964 godah[The system of benefits for migrants to the Crimea in 1944-1964] Uchenye zapiski Tavricheskogo nacional'nogo universiteta im. V. I. Vernadskogo. Seriya «Istoricheskie nauki», 23 (62), 1: 180-186.

Seitova, E.I. 2010 Proces sil's'kogospodars'koï migraciï do Krimu protyagom 1944-1953 rokiv [The process of agricultural migration to the Crimea during 1944-1953] «Sivershchina $v$ istorii Ukraïni»: zbirnik naukovih prac 3: 317-320

Sidorenko, N.A. 2012 Migraciya i etnicheskie processy v Krymu v 40-70-e gody HKH veka [Migration and ethnic processes in Crimea in the 40-70s of the XX century] Voprosy duhovnoj kul'tury - ISTORICHESKIE NAUKI 238: 141-145

Sokolov, D. 2012 CHernoevremyaTavridy: Krymskayaderevnyaigolod 1921-1923 gg. [Black time of Taurida: Crimean village and famine of 1921-1923] Pravoslavnyj informacionnyj portal «Russkaya liniya». https://rusk.ru/st.php?idar=55994

Verbickaya, O. M. 1986. Planovoe sel'skohozyajstvennoe pereselenie v RSFSR v 1946-1958 godah [Planned agricultural resettlement in the RSFSR in 1946 - 1958]. Voprosy istorii 12: 13-26.

Volkov. A.G. 1990 Perepis' naseleniya SSSR 1937 goda. Istoriya i materialy [Population census of the USSR in 1937. Historyandmaterials] Ekspress-informaciya. Seriya "Istoriyastatistiki" 3-5 (p. 2): 6-63.

Volobuev, O.V. 2016 Sel'skoe hozyajstvo Kryma v poslevoennye (1944-1953) gody: dinamika i tendencii razvitiya [Agriculture of Crimea in the post-war (1944-1953) years: dynamics and development trends] Vestnik Moskovskogo gosudarstvennogo oblastnogo universiteta. Seriya: Istoriya i politicheskie nauki 4: 92-100

Zarubin, V. G. 2013 Proekt «Ukraina». Krym v gody smuty 1917-1921 gg. [Project "Ukraine”. Crimea duringthe Troubles 1917-1921]. Kharkiv: Folio Publishing House. 